\title{
Lissemys punctata (Bonnaterre 1789) - Indian Flapshell Turtle
}

\author{
S. Bhupathy ${ }^{1}$, Robert G. Webi ${ }^{2}$, and Peter Praschag ${ }^{3}$ \\ ${ }^{1}$ Salim Ali Centre for Ornithology and Natural History, \\ Anaikatti(PO),Coimbatore, 641108 India [bhupathy.s@gmail.com]; \\ ${ }^{2}$ Department of Biological Sciences, The University of Texas at El Paso, \\ El Paso, Texas 79968 USA [rgwebb@utep.edu]; \\ ${ }^{3}$ Turtle Island,Puntigamerstrasse 7,8041 Graz,Austria [peter@praschag.at]
}

Summary. - The Indian Flapshell Turtle, Lissemys punctata (Family Trionychidae), is a relatively small softshell turtle with a carapace length of up to $350 \mathrm{~mm}$. Three intergrading subspecies are confined to the Indian subregion. Individuals are adaptable and durable, occurring in a variety of aquatic habitats, ranging from rivers and streams to reservoirs, marshes, ponds, lakes, and even salt marshes, rice fields, gutters, and canals in metropolitan areas. It is common in brackish water lagoons on the east coast of India, and is often abundant in irrigation canals and tanks, and paddy fields with stagnant water. The species is not plentiful in the main channels of rivers or in large canals, but seems to prefer relatively shallow waters. Lissemys punctata is omnivorous and can survive periods of drought by estivating for a long time on land. Nesting generally occurs in late summer and extends into the monsoon season, July through November. Clutch size varies from 4-15 eggs, which generally have a prolonged incubation period of $>300$ days. Despite extensive exploitation by man as a food source for many years, these turtles are still fairly common and seem to be holding their own, with populations relatively stable and not yet seriously threatened.

Distribution. - Bangladesh, India, Myanmar, Nepal, Pakistan. Distributed in the Indian subregion from the Indus basin of Pakistan through India, Nepal, and Bangladesh to northeast Inda and extreme western Myanmar. Populations on Sri Lanka formerly considered to belong to this species have recently been recognized as the distinct species $L$. ceylonensis.

Synonymy. - Testudo punctata Lacépède 1788 (nomen rejectum), Testudo punctata Bonnaterre 1789, Trionyx (Emyda) punctatus, Trionyx punctatus, Emyda punctata, Trionyx punctata, Lissemys punctata, Lissemys punctata punctata, Trionyx punctatus punctatus, Testudo sonnerati Meyer 1790, Testudo granulosa Suckow 1798, Testudo scabra Latreille in Sonnini and Latreille 1801, Testudo granosa Schoepff 1801, Trionyx granosus, Cryptopus granosus, Emyda granosa, Emyda granosa granosa, Lissemys punctata granosa, Trionyx punctatus granosus, Testudo granulata Daudin 1801, Trionyx coromandelicus Geoffroy Saint-Hilaire 1809, Emyda dura Anderson 1876.

SubSPECIES. - Currently three subspecies are recognized: 1) Lissemys punctata punctata (Southern Indian Flapshell Turtle) (distribution: southern peninsular India [Kerala, Tamil Nadu]); 2) Lissemys punctata andersoni (Spotted Northern Indian Flapshell Turtle) (synonymy: Lissemys punctata andersoni Webb 1980, Lissemys andersoni) (distribution: Bangladesh, northern India [Assam, Bihar, Haryana, Jammu, Madhya Pradesh, Meghalaya, Rajasthan, Sikkim, Uttar Pradesh, West Bengal], Myanmar, Nepal, Pakistan); and 3) Lissemys punctata vittata (Central Indian Flapshell Turtle) (synonymy: Emyda vittata Peters 1854, Emyda granosa vittata, Lissemys punctata vittata, Emyda granosa intermedia Annandale 1912) (distribution: central India [Andhra Pradesh, Chhattisgarh (?), Goa, Gujarat, Karnataka, Madhya Pradesh, Maharashtra, Orissa, Rajasthan]).

StaTuS. - IUCN 2013 Red List: Least Concern (LC, assessed 2000); TFTSG Draft Red List: Least Concern (LC, assessed 2011); CITES: Appendix II; Indian Wildlife (Protection) Act, Schedule I; Bangladesh Wildlife Preservation (Amendment) Act (BWPA), Schedule II.

Taxonomy. - Testudopunctata was originally described by Lacépède (1788). The ICZN (1987, Opinion 1463) ruled that several of Lacépède's works were unavailable for purposes of zoological nomenclature, but, as noted by Bour (1989), this did not originally include Volume I(1788), which was still nomenclaturally available. However, a subsequent proposal by Savage (2003) for rejection of Lacépède's 1788 Histoire Naturelle (Vol. I) and subsequent editions as an unavailable, non-binomial work was approved by the ICZN (2005). Thus, Bonnaterre (1789), who used Testudo punctata 


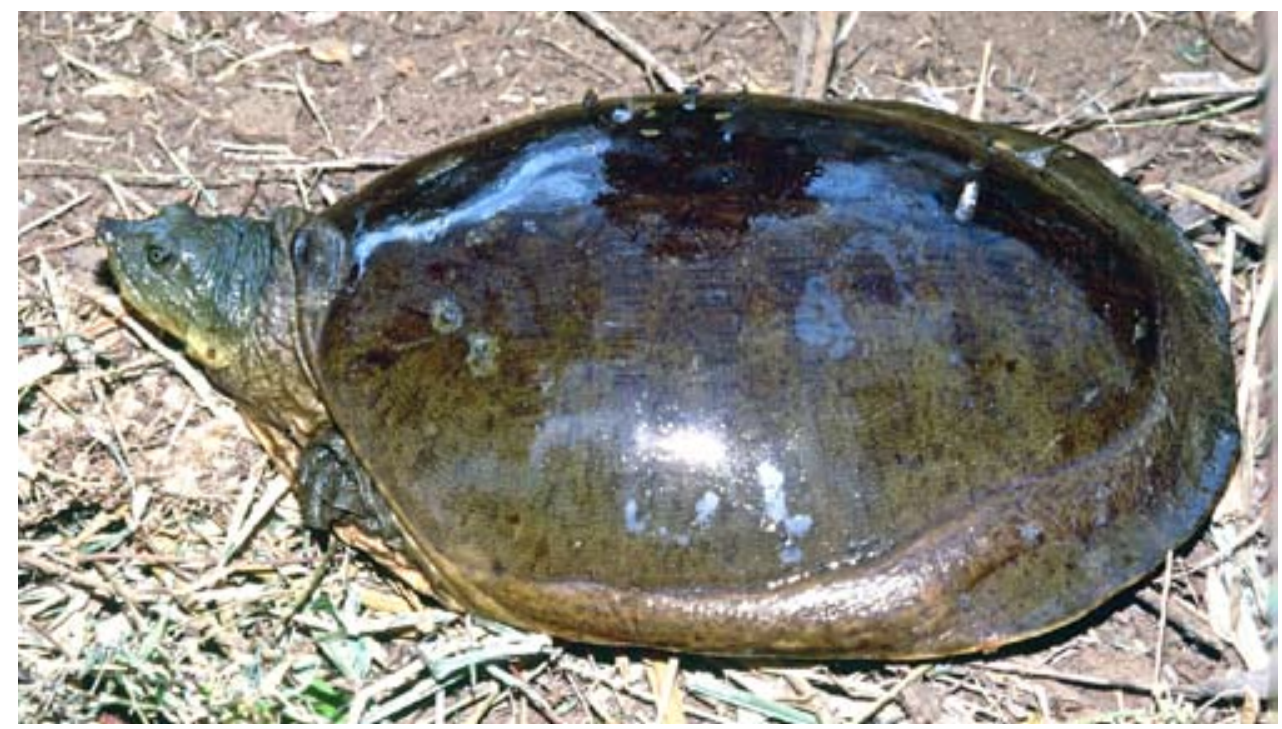

Figure 1. Adult Lissemys punctata punctata from Mamallapuram, Tamil Nadu, India. Photo by Indraneil Das.

in his reiteration of Lacépède's description and copied his illustration, is now regarded as the author of the valid name Lissemys punctata.

The specific status of $L$. punctata has not been questioned since the original description, but the species has been recognized by several different name combinations. Several authors assigned the species to the genus Trionyx (e.g., Mertens and Wermuth 1955). Gray (1831) proposed Emyda for this species, and Duméril and Bibron (1835) changed both the generic and specific names, using Cryptopus granosus, the specific name stemming from Schoepff's (1801) name Testudo granosa. The name Emyda granosa became entrenched as the name for the Indian Flapshell Turtle in the literature for a while through its use by Boulenger (1889), Siebenrock (1902, 1909), and Annandale (1912). Smith (1931), noting senior homonyms of both Emyda (initially by Baur 1893) and Cryptopus, proposed the new generic replacement name Lissemys and reverted to using punctata as the correct specific name. Some additional information regarding taxonomic history and nomenclature of this species is noted in Webb (1980).

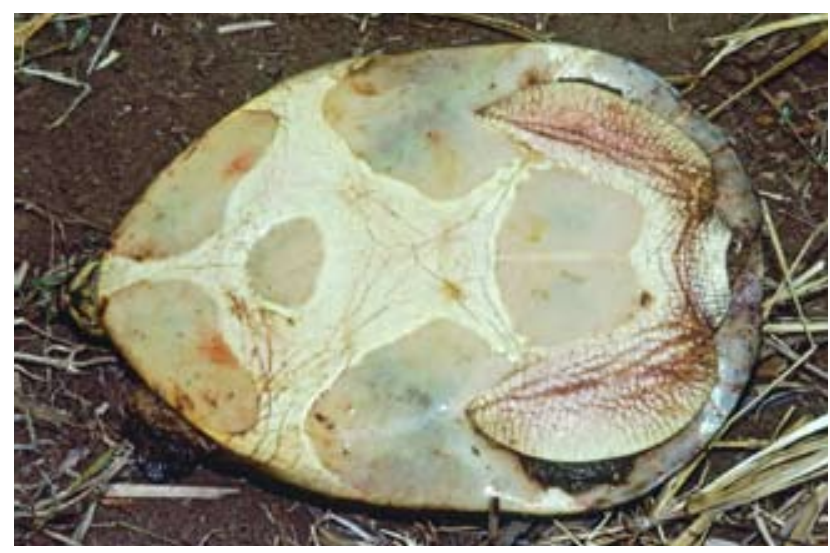

Figure 2. Adult Lissemys punctata punctata from Mamallapuram, Tamil Nadu, India. Photo by Indraneil Das.
Smith (1931) reduced the five subspecies recognized by Annandale (1912) to three: L.p.punctata, L.p. granosa, and L. p. scutata. Until relatively recently, the name $L . p$. punctata was applied to the yellow-spotted form in northern India. However, allocation of the type locality (holotype) of L. punctata to Pondicherry, Tamil Nadu, on the Coromandel Coast of southern India, resulted in recognition of L. $p$. punctata as the valid name for the form in southern peninsular India (Webb 1980). Consequently, the northern subspecies (having no nominal subjective synonyms or available alternative names) required a new name, L. p. andersoni (Webb 1980). The Burmese subspecies from Myanmar was later elevated to a distinct species, Lissemys scutata (Webb 1982).

Genetic analysis of four geographically isolated populations of $L$. punctata based on seven metabolically important isozyme/allozymes showed significant genetic diversity among them (Rohilla et al. 2009). The Indian Lissemys are reportedly closely related to African flapshells (Joyce and Lyson 2010).

Praschag et al. (2011) investigated the relationships among Asian flapshell turtles using 2286 bp of mitochondrial

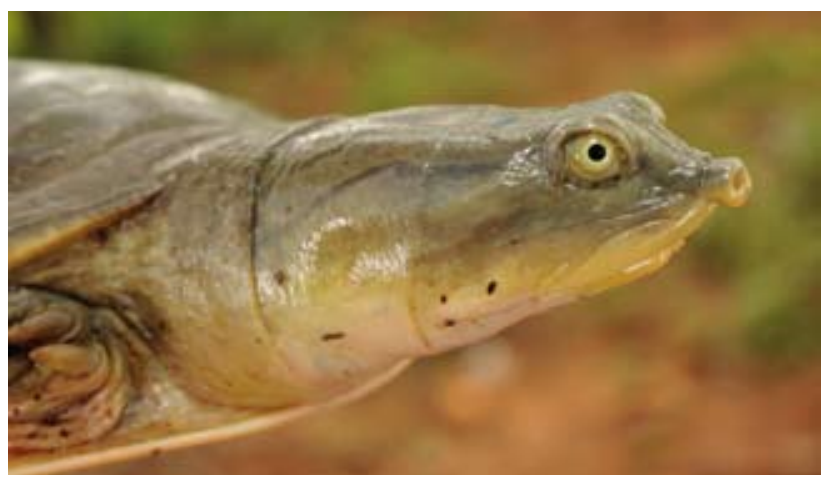

Figure 3. Juvenile Lissemys punctata punctata from Moyar River, Karnataka-Tamil Nadu border, India. Photo by Peter Praschag. 


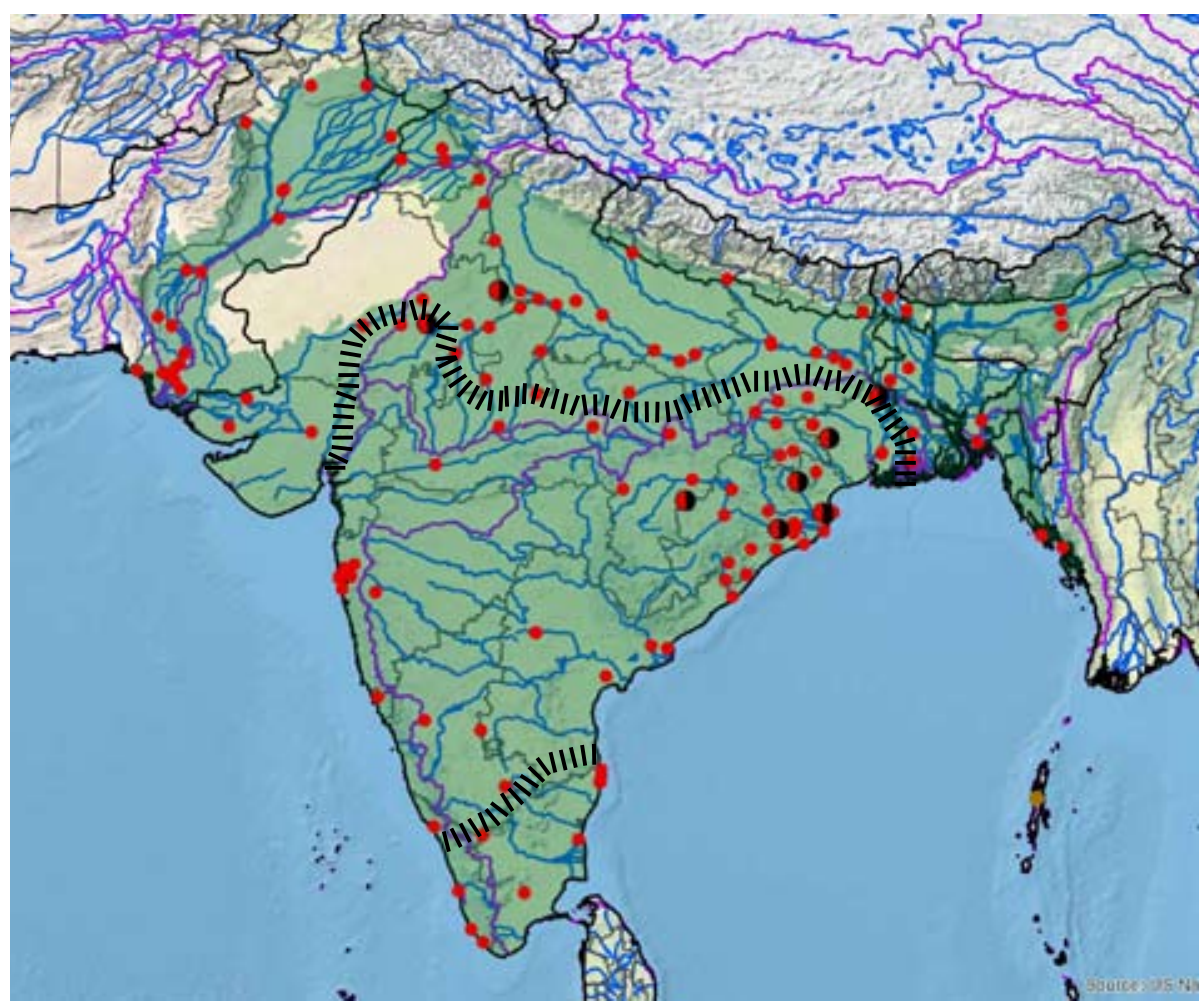

Figure 4. Distribution of Lissemys punctata in Pakistan, India, Nepal, Bangladesh, and Myanmar in the Indian subregion of Asia. Purple lines = boundaries delimiting major watersheds (level 3 hydrologic unit compartments - HUCs); red dots = museum and literature occurrence records of native populations based on Iverson (1992), plus more recent and authors' data; brown dot $=$ occurrence record of presumed introduced population in the Andaman Islands; red/black dots = hybrid specimens of L. p. vittata $\mathrm{x}$ andersoni as determined genetically by Praschag et al. (2011); green shading = projected native distribution based on GIS-defined HUCs constructed around verified localities and then adding HUCs that connect known point localities in the same watershed or physiographic region, and similar habitats and elevations as verified HUCs (Buhlmann et al. 2009), and adjusted based on authors' subsequent data; cross-hatched lines $=$ approximate boundaries between the three subspecies as detemined genetically by Praschag et al. (2011), with L. p.punctata in the extreme south, L. p. andersoni in the north from southern Pakistan across northern India, Nepal, Bangladesh and western Myanmar, and L.p. vittata in central peninsular India, with a large and wide area of partial intergradation with L. p. andersoni in eastern India.

DNA and found five deeply divergent clades; one corresponded to L. scutata from Myanmar and a second one to L.p.andersoni from the Indus, Ganges, and Brahmaputra drainages of Pakistan,Nepal,northern India,Bangladesh, and western Myanmar.Three distinct clades were identified within L. p. punctata: two from central and southern peninsular India and one from Sri Lanka. The two clades from India were more closely related to L.p. andersoni than to the one from Sri Lanka. For the central Indian clade the authors revalidated the name L. punctata vittata. For the Sri Lankan

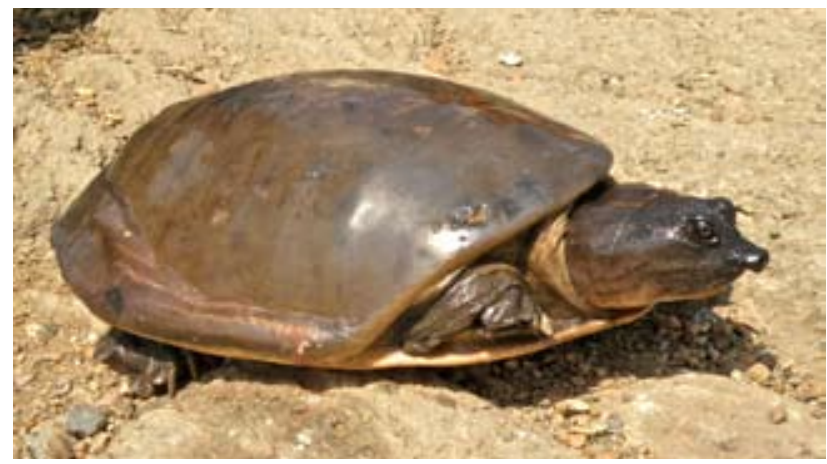

Figure 5. Adult male Lissemys punctata vittata, Mahanadi River, Orissa, India. Photo by Shailendra Singh. clade, due to the degree of genetic divergence resembling $L$. scutata, they proposed that these populations be elevated as the distinct species L.ceylonensis (Gray 1856), separate from L. punctata. Thus, three subspecies of Lissemys punctata are currently recognized: L.p.punctata, L.p. andersoni, and $L$. p. vittata.

Description. - Femoral flaps and nasal septal ridges are present. Shell closure (femoral flaps and moveable anterior plastral lobe) allows for complete concealment of head, neck, and limbs and thus protection from predators and desiccation

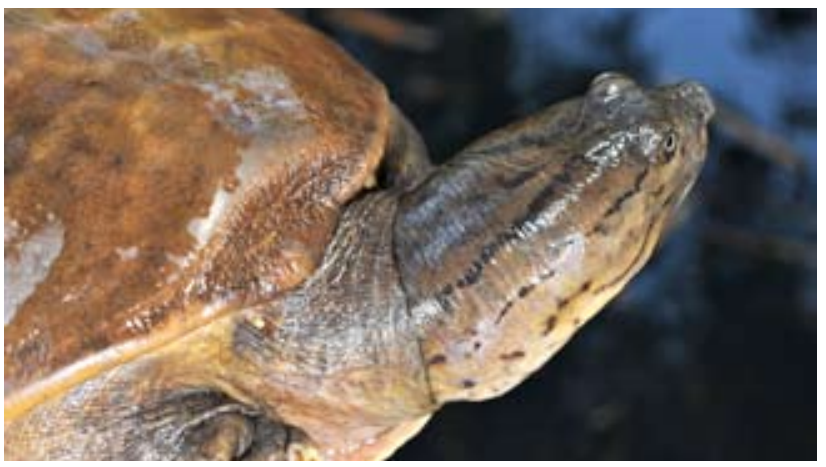

Figure 6. Lissemys punctata vittata, Netravati River, Karnataka, India. Photo by Peter Praschag. 

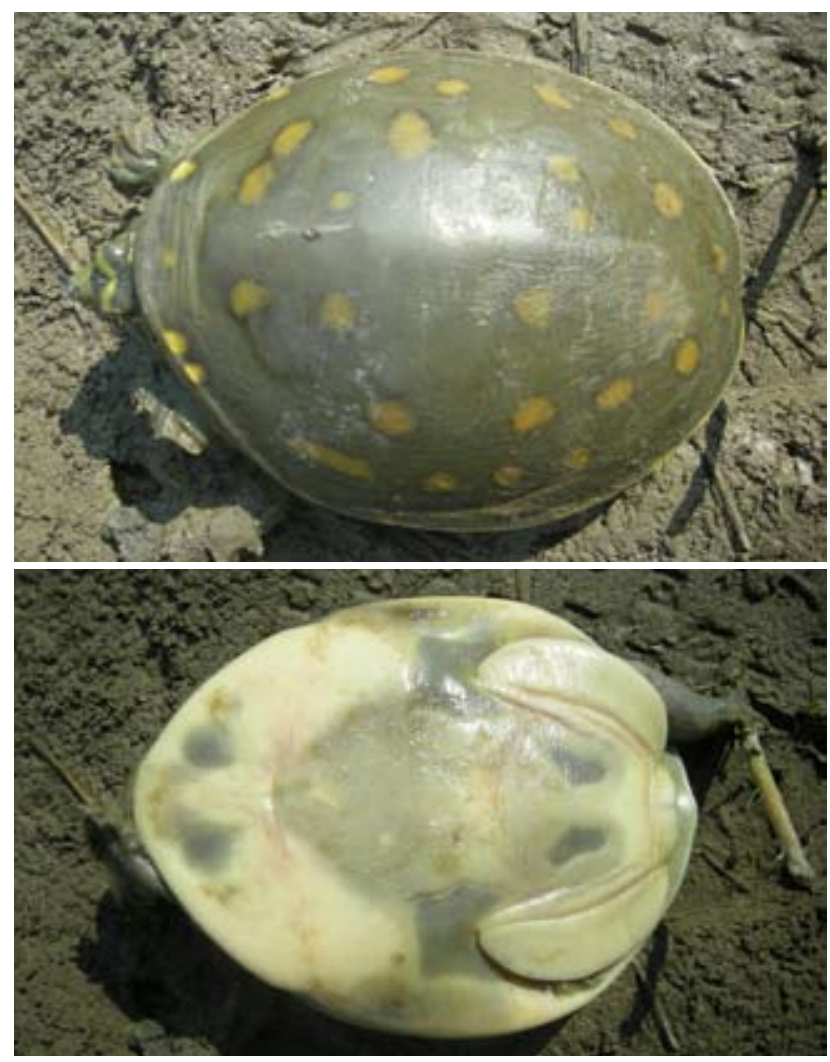

Figure 7. Subadult Lissemys punctata andersoni, Ghaghra River, northern India. Photos by Shailendra Singh.

(Auffenberg 1981). The carapace is relatively humped and smooth-surfaced in juveniles and adults, but hatchlings have low, indistinct ridges of tubercles, most prominent along the lateral margins. Das (1991) reported the young to have granules forming longitudinal folds. Young and adults have a complete marginal ridge (seam paralleling anterior rim of carapace) with little modification in the nuchal region. The antebrachial scalation consists of four to six curved, cuspedged scales that are distal to the upper marginal completely smooth scale.

The carapace shape is nearly circular in hatchlings, more oval in adults. Adult females are larger than males (Auffenberg 1981; Agarwal 1987; Shrestha 1997). The maximal (curved) carapace length (CL) of females is 350

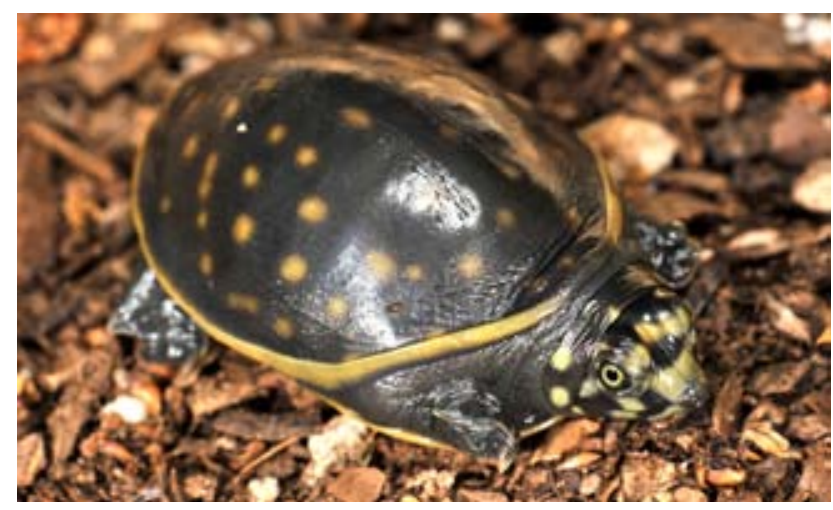

Figure 9. Hatchling Lissemys punctata andersoni. Photo by Peter Praschag.

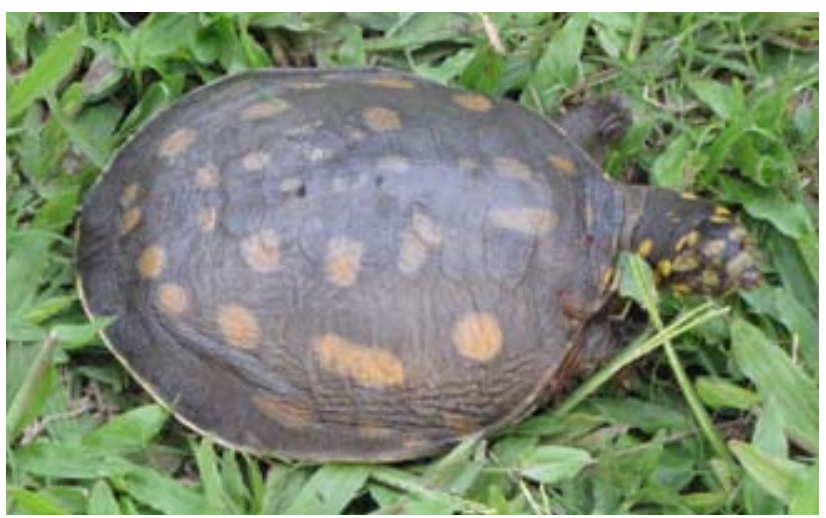

Figure 8. Juvenile Lissemys punctata andersoni, Assam, northeast India. Photo by Chittaranjan Baruah.

mm [estimated PL $334 \mathrm{~mm}$ ] (Bhupathy 1989). Maximal CL size of a sample of 10 males from eastern Utter Pradesh, India, was $230 \mathrm{~mm}$ (Yadava and Prasad 1982). Vyas (1996) recorded average dimensions of six clutches of hatchlings ( $\mathrm{n}$ $=40$ ) noting the carapace length $(\mathrm{CL})$ mean $=35.7 \mathrm{~mm}$, range $=34.8-37.0 \mathrm{~mm}$ and mass, mean $=6.0 \mathrm{~g}$, range $=8.0-10.0$ g. Rashid and Swingland (1997) recorded hatchlings with $\mathrm{CL}=35-44 \mathrm{~mm}$. Minton (1966) reported a hatchling $(L$. p. andersoni from Pakistan, taken 27 July) with a $\mathrm{CL}=35$ $\mathrm{mm}$.

There is no sexual dichromatism, but differences in head and carapace patterns distinguish L.p. andersoni from the other two subspecies. Ventral surfaces are whitish, unpatterned, and the limbs are uniformly pigmented. The carapace and soft body parts of L. p. punctata and L. p. vittata are olive-green to brownish, but greener in young specimens. Praschag et al. (2011) were unable to correctly differentiate specimens of the two subspecies of unspotted flapshells from the Indian peninsula (L.p. punctata and L.p. vittata), as they are very similar in appearance. The carapace may have some small dark markings, but no prominent distinctive pattern. The juvenile dark-striped pattern on the rear of the head tends to disappear with age (Das 1991). The entoplastral callosity in adults tends to be larger in $L . p$. punctata and L. p. vittata than in L. p. andersoni, but this character is strongly affected by ontogeny. The subspecies L. p. andersoni has an olive-green carapace and soft body parts, with yellow blotches and hieroglyphs on the carapace and head and neck. The blotches tend to disappear in old individuals (Smith 1931). Vyas (1997) reported an albino specimen from Gujarat (uniformly yellow carapace, head, and limbs, the plastron light yellow with pink callosities, and pink eyes). Hossain and Sarkar (1999) also reported an albino Lissemys punctata from Bangladesh and Praschag (unpubl. data) recorded three albinos from Arakan, Myanmar.

The skull has vomer-prefrontal struts, the postorbital arch narrower than the horizontal diameter of the orbit, a closed fenestra postotica (broad ascending strut of pterygoid sutured to opisthotic), and a short maxillary bridge (between 


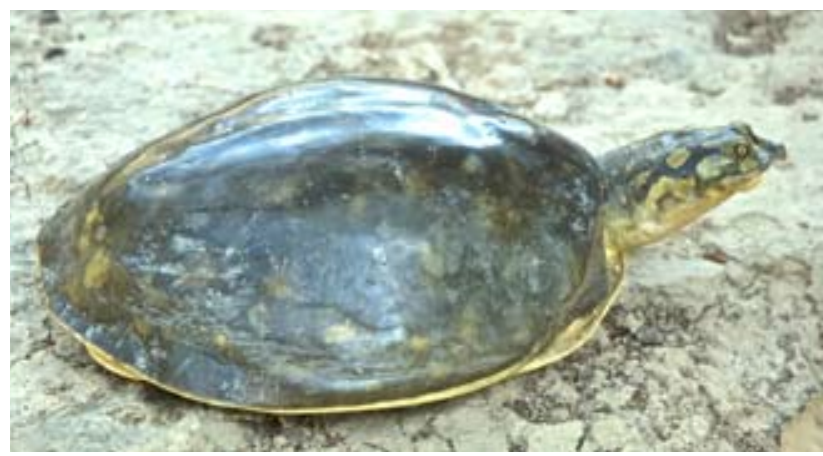

Figure 10. Adult female Lissemys punctata vittata $\mathrm{x}$ andersoni from Keoladeo National Park, Bharatpur, Rajasthan, India. Photo by Anser Khan.

the foramen intermaxillaris and the opening of internal nares). The body of the hyoid consists of three pairs of bones and the posterior horn is not subdivided (i.e., it consists of a single curved element).

The bony carapace has a distinctive, sandpapery or sharkskin texture, contrasting with the relatively coarsely pitted texture in most trionychid species. The carapace has a prenuchal bone (initially isolated but sutured to the nuchal in large adults), two neurals between the first pair of pleurals, and a diagonally oriented suture between the nuchal and the first pleural (forming laterally expanded first pleurals). The nuchal (ventral view) is bifid or notched on either side (costiform processes). There are six to nine (usually eight) neurals with one or two pairs of the posteriormost pleurals sutured medially; the last (eighth) pair of pleurals is subtriangular in shape. The rear half of the bony carapace has posteriorly tapered and somewhat concave lateral margins. There is a series of juxtaposed but unsutured peripheral elements, the anteriormost being the largest, that are not connected to the ribs or to the rest of the carapace, and that may or may not be homologous with the peripherals of hardshelled turtle species. The number of peripherals seems to vary ontogenetically, with the smallest number in the largest turtles, the reduction presumably occurring by fusion between adjacent elements.

The plastron has well developed callosities on all bones, except that the isolated entoplastral callosity varies greatly in size, and may be absent (Bhupathy 1989). The hyo- and hypoplastra are fused on each side, without visible suture, and share a very large callosity that, in large adults, is enlarged anteriorly and almost contacts the posterolateral enlargement of the epiplastral callosity to form the lateral margin of the carapace; thus, replacing the peripheral bones in this area of the shell. The epiplastra are straight (not angular) and sutured to the entoplastron. A single prong projects medially from the hypoplastron, and the middle prong of the posteriomedial process of the hypoplastron interdigitates with the xiphiplastron.

The diploid chromosome number is 66 (Bickham et al. 1983).

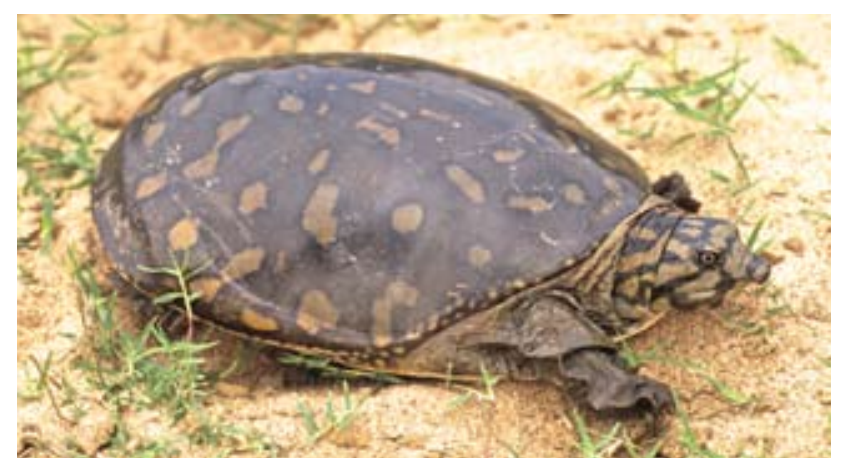

Figure 11. Adult Lissemys punctata vittata $\mathrm{x}$ andersoni from Subarnarekha River, Orissa, India (with vittata mitochondrial haplotype). Photo by Peter Praschag.

Distribution. - Lissemys punctata is restricted to the Indian subregion. The nominotypical subspecies occurs in southern peninsular India, in the states of Kerala and Tamil Nadu. The subspecies L. p. andersoni occurs in Pakistan, northern India and southern Nepal, east into Bangladesh in the Indus and Ganges-Brahmaputra drainage systems, and in northwestern coastal Myanmar (Burma). The subspecies L. p. vittata occurs in peninsular India from Gujarat south to Karnataka in the west to Orissa and Andhra Pradesh in the east. Smith (1931) noted that this species occurs from sea level to $1000 \mathrm{~m}$ a.s.l. Specific records of occurrence are provided for the whole region by Das (1991, 1995, 2001), and for Nepal by Mitchell and Rhodin (1996) and Schleich and Kästle (2002). Talukdar (1979) reported this species from the Brahmaputra flood plains, Assam, India, and Das and Gupta (2010) from Barak Valley of the same state.

Das (in litt.) noted that specimens introduced in the Andaman Islands are yellow-spotted (= L. p. andersoni) and have been collected only close to Bengali settlements in the Port Blair area. Yong (1990) found a skeleton of $L$. punctata from Seleter reservoir, Singapore, and reported that it could be from a release of captive turtles. Choudhury et al. (2000) noted the species as introduced in the desert regions of India. The relatively wide distribution of this species, including many seasonally arid regions, reflects the remarkable morphological (complete shell closure) and behavioral (estivation) adaptations for protracted survival under drought conditions.

Turtles having morphologically intermediate patterns on the head and carapace generally occur across northern India, mostly south of the Ganges River drainage. Reported intergrades between L. p. andersoni and L. p. vittata are known from the states of Bihar, West Bengal, Orissa, and Rajasthan (Webb 1982), Madhya Pradesh (Das 1991), and the Kathiwar peninsula, Gujarat (Frazier and Das 1994). Shrestha (1996) observed that 10 live specimens with unusual markings were caught at two localities near Rajapur, Nepal; Shrestha considered that the specimens were intermediate between $L . p$. vittata, with black lines on the head and a plain or strikingly patterned carapace, and $L . p$. andersoni 
with yellow markings on the carapace. Rashid and Khan (2000) reported the unspotted subspecies as uncommon in southern Bangladesh. Lissemys p. vittata occurs naturally in the south and southwest of Bangladesh, but their numbers are very low $(<1 \%)$ and L. p. andersoni is quite common there (Rashid, pers. comm.). In analyzing mitochondrial DNA sequences, a spotted L. p. andersoni specimen from the Subanarekha River, Orissa, India, showed the same haplotype as an unspotted L.p. vittata and five specimens of unspotted specimens from Chilka Lake, Orissa, conflicting with the observed morphology (Praschag et al. 2011). There is no information available about intergradation between $L$. p. punctata and L. p. vittata.

Habitat and Ecology. - Lissemys punctata occurs in a variety of aquatic habitats, ranging from rivers and streams to reservoirs, marshes, ponds, lakes, and even salt marshes, rice fields, gutters, and canals in metropolitan areas (Das 1991, Moll and Moll 2004, Hossain et al. 2008). This species appears to tolerate salt water conditions well, as it is common in brackish water lagoons in the Sunderbans (West Bengal), Bhitarkanika (Orissa), and Coringa (Andhra Pradesh) of the east coast of India. It is often abundant in irrigation canals and tanks, and paddy fields with stagnant water (Rashid and Swingland 1977). Minton (1966) noted that they are not plentiful in the main channels of rivers or in large canals. Turtles seem to prefer relatively shallow waters, which may be devoid of aquatic vegetation, and they may spend long periods shallowly buried in the mud bottoms. Turtles bask on banks of rivers and ponds and on floating vegetation (Minton 1966; Das 1991). Activities are geared to the winter (generally November into February), summer (March into July), and monsoon (July into November) seasons that vary somewhat with latitude.

Movements and Estivation. - Overland movements occur in response to either drought conditions, or increased water depth during the rainy season. In the latter instance, turtles move overland into shallow pools; when these dry up they move back into the larger, permanent sites. Turtles move overland, burrow, and estivate when shallow ponds and lakes dry up in the summer months (peak in May); larger sites may go dry in later months if drought conditions persist into the monsoon seasons. Auffenberg (1981) suggested that water temperatures higher than $35^{\circ} \mathrm{C}$ may be most important in determining emergence from drying pools. He noted overland movements between 0900 and 1640 $\mathrm{hrs}$, the farthest distance $1050 \mathrm{~m}$ from water, and estivation sites in thick grass or forested areas where turtles bury to a depth of 3-6 cm (surface to top of carapace). Bhupathy and Vijayan (1994) reported a mean depth (surface to top of carapace $)$ of $5.02(2-10) \mathrm{cm}(\mathrm{n}=304)$, higher density of estivation sites under bushes closer to dried marshes, and a density of 950 estivating turtles/ha. The maximal duration of estivation recorded for turtles in wild populations is 160 days. The estivation-site temperature in open dried marshes during midday hours may be as high as $48^{\circ} \mathrm{C}$, exceeding the ambient air temperature, and is higher than the critical thermal maximum of at least some other trionychid turtles (Apalone spinifera aspera, $41.05^{\circ} \mathrm{C}, 39.9-42.3^{\circ} \mathrm{C}, \mathrm{n}=10$; Hutchison et al. 1966), indicating a high temperature tolerance in $L$. punctata. Annandale (1912) reported hibernating turtles (buried in mud substrate) in ponds in winter months in the northern part of the range. Das (1991) noted hibernation from November to February in northern India, with males becoming inactive prior to females and emerging later than females.

Diet. - The species is an opportunistic omnivore. Varghese and Tonapi (1986) reported that captives were omnivorous. Food items include adult frogs, tadpoles, fish, crustaceans, molluscs, earthworms, insects, carrion, and water plants (Sharma and Vazirani 1977; Tikader and Sharma 1985; Das 1991; Schleich and Kästle 2002). Bhupathy and Vijayan (1993) quantified the diet analyzing scats $(\mathrm{n}=71)$ and found plants (34\%), insects (20\%), molluscs (26\%), and fish (20\%). The molluscs include both snails (Lymnaea, Gyrulus, Palidomus) and bivalves. Aside from aquatic insects and larvae, the species eats terrestrial insects that may fall into the water (Orthoptera, Coleoptera, Hemiptera, Hymenoptera).Aquatic plants consumed include grass, water lilies (Nymphoides, Nymphaea), bladderwort (Utricularia), and some seeds and fruits.

Das (1995) noted a seasonal shift in diet in northern India from the normally carnivorous diet to herbivory just before and after hibernation. Das (1991) reported captives that ate mosquito larvae. Minton (1966) reported a large captive adult from Pakistan that killed and ate a small hardshelled turtle (Pangshura sp.) confined with it.George (1986) reported cannibalism in this species at Keoladeo National Park,Bharatpur,Rajasthan.Das (1991) described burrowingambush behaviors to catch fish. However, Bhupathy and Vijayan (1993) indicated that most fish were dead or dying and consumed in the summer when ponds were drying up. Daniel (1983) reported a captive that endured prolonged starvation of two years.

Sexual Maturity. - Specific data on size and/or age at attainment of sexual maturity in this species are few. Yadava and Prasad (1982) reported turtles with $\mathrm{CL}<160 \mathrm{~mm}$ as immature, and males are smaller in size at maturity compared to females. Yadav (1989) considered females above $170 \mathrm{~mm}$ straight CLas sexually mature. The smallest female of which Yadav collected eggs had a CL of $187 \mathrm{~mm}$ and weight of $684 \mathrm{~g}$.

Reproduction. - The reproductive cycle of L.punctata differs according to geographic region and it seems that it is closely correlated with monsoon seasons and heavy rains (Gramentz 2011). Aquatic mating occurs in April (Duda and Gupta 1981), involving the male with head extended 
circling the female, head-bobbing of both sexes that face each other with necks extended, and copulation on the bottom with subsequent rotation of the male to face the opposite direction. However, Bhupathy has observed the male biting the anterior edge of the female's carapace, and turtles in copula floating at the surface (Bhupathy and Buhlmann 2010). Vyas (1996) also observed courtship behavior in April and noted the forelimbs of the male tickling the extended neck of the female, and also stroking both sides of her head; the male then swam clockwise around the female.

Spermatogenesis occurs in late April, peaking in June (Raghuwanshi in Das 1991).Sarkar et al.(1995) commented on histological changes of oviducts during the seasonal reproductive cycle. However, Singh (1977), in sampling the population near Varanasi, India, noted general synchrony of male and female seasonal gonadal activity with the onset of gonad enlargement in March-April(occasional spermatozoa), maximal gonadal development peaking in July and August (coinciding with longest day-length), followed by progressive regression. It is reported that higher temperature triggers the ovarian growth and secretion of estrogen at the early stage of reproduction, and once the ovarian function is set in, temperature plays a regressive role (Sarkar et al. 1996a). The female reproductive cycle of L.punctata was reportedly long-ranging from March to September (Sarkar et al. 1996b). Sarkar et al. (2003) reported sperm storage in the oviduct, and the stored sperm remained viable for at least six months. Transabdominal migration of ova has been reported in this species (Duda and Gupta 1982). Singh (1977) emphasized breeding in July-August, a period with monsoons and thus heavy rainfall and highest relative humidity. Yadav (1989) reported this species as an annual breeder and shelled eggs were observed during September-November in the north Indian State of Uttar Pradesh. However, in Bangladesh, Rashid and Swingland (1997) reported multiple clutches between August and March.

Nesting. - Nesting generally occurs in late summer, extending into the monsoon season, July through November. Turtles inhabiting perennial rivers may move through canals to find suitable nesting sites in loamy soil. Minton (1966) reported nest excavation (slow movement of hind limbs) about seven feet from the pond edge. Das $(1985,1991)$ reported nests $8-10 \mathrm{~cm}$ deep, close to water, either under cover of thorny bushes or fully exposed. Sandy areas are not preferred for nesting. Rashid and Swingland (1997) noted bowl-shaped nests (15-18 cm deep), 10-30 m from water, in backyard gardens, bamboo groves, pond banks, and even in fallow land separating paddy fields. Mishra (1986) reported a nest depth of $23 \mathrm{~cm}$ ( $\mathrm{egg}$ depth, $19 \mathrm{~cm}$ ) in muddy soil and $220 \mathrm{~cm}$ from the edge of the Chambal River.

Clutch size varies from 2-15 eggs. Larger females tend to deposit more eggs than smaller females, with egg size decreasing with increasing clutch size (Yadava and Prasad
1982; Das 1991). The eggs are white, nearly spherical, and brittle-shelled. Minton (1966) reported egg diameters of 24-30 mm, Rashid and Swingland (1997) 24-33 mm [mean $26 \mathrm{~mm}$, mass $14.75 \mathrm{~g}, \mathrm{n}=105$ ], Mishra (1986) $27.3 \mathrm{~mm}$ (n $=7$, mass $11 \mathrm{~g}$ ) and Yadav (1989) an average of $23.9 \mathrm{~mm}$ ( $\mathrm{n}$ $=14,8.75 \mathrm{~g}$ ). Rashid and Swingland (1997) recorded three nests, on 26 August (28 eggs, probably two clutches), 26 December (14 eggs), and 11 March (12 eggs).

Khan (2006) noted an incubation period of 30-40 days in Pakistan, which is the lowest recorded and perhaps unusual. Lengthy incubation periods of 270-317 days at $32.6^{\circ} \mathrm{C}$ are based on observations under artificial conditions (Das 1991). Vyas (1996) recorded data from 7 egg clutches laid by semicaptives subject to environmental conditions: clutch size (9-15 eggs), times of deposition (7 June-28 September), average egg dimensions (ca. 26-28 mm), and mass $(10.5-13.3 \mathrm{~g}, \mathrm{n}=5)$, incubation periods $(241-412$ days, $n=6$ ), and dates of hatching ( 6 June- 8 August, all the following year, $\mathrm{n}=6$ clutches). One of these nests, deposited 18 June 1994, was completely flooded for 22 hours on 6-7 September, but 10 hatchlings successfully emerged on 11 July 1995 (389 days incubation); one more emerged on 3 August. Rashid and Swingland (1997) noted hatching during May-July. Some eggs presumably are laid and hatch during the same monsoon season (Daniel 1983), whereas others in the Madras area do not hatch before the next rains the following year (Vijaya 1982, Das 1991).

Hatchlings and small juveniles are most common during the rainy season. Whitaker and Andrews (1997) noted nesting all year in the Madras area. Reproductive aspects seem to vary seasonally in concert with latitude and are geared to rainfall.

Predation. - Aside from human exploitation for food, mortality is caused by a variety of predators. Antipredator adaptations include the ability to completely close the shell (concealing soft body parts), and to secrete from the two pairs of Rathke's glands (Erhenfeld and Erhenfeld 1973) an egg-yolk like fluid that has an objectionable odor and presumably bad taste (Auffenberg 1981). Khan (2006) noted variation in temperament of individuals, with some being docile, allowing free handling, whereas others hissed loudly and lunged with open mouth, voiding the foul-smelling secretions.

Aquatic predators include Mahseer fish (Tor sp.), Mugger Crocodile (Crocodylus palustris), and the Indian Softshell Turtle (Nilssonia gangetica) (Bhupathy and Vijayan 1989; Bhupathy 1990; Das 1991; Schleich and Kästle 2002). The White Scavenger Vulture (Neophron percnopterus) is an important predator when shallow ponds dry up in summer (Auffenberg 1981; Bhupathy and Vijayan 1989);Auffenberg noted that the birds preyed mostly on the smaller-sized turtles. Bhupathy and Vijayan (1989) recorded three other vulture species (Red-headed Vulture, Sarcogyps calvus, 
White-rumped Vulture, Gyps bengalensis, Cinereous Vulture, Aegypius monachus), eagles (Aquila spp.) and crows (Corvus splendens, C.macrorhynchos) as predatory associates.After two successive years of drought, Bhupathy and Vijayan (1989) estimated that predator pressure affected about 50 percent of this Lissemys population, as revealed by varying degrees of leg loss (a handicap for males during mating and females during nest excavation). Sivasubramanian and Bhupathy (1990) reported an Adjutant Stork (Leptoptilos dubius) that ate a small Lissemys. Auffenberg (1981) noted that some estivating Lissemys were killed and eaten by foraging wild pigs (Sus scrofa), and that mortality may result from trampling by water buffalo (Bubalus bubalis) at the edge of drying ponds that forces turtles deep into the thick drying mud from which they cannot free themselves. Mishra (1987) also reported eggs eaten by jackals along the Chambal River and egg damage by termites at Kukrail, near Lucknow. Eggs also are food for monitor lizards (Varanus sp.) and the Rhesus Macaque (Macaca mulatta). Daniel (1983) and Das (1991) noted a filamentous alga on the neck, limbs and shell.Leeches (Placobdella emydae) infest L.punctata (Das 1991). Parasites (trematodes and protozoans) are recorded in Schleich and Kästle (2002) and Gramentz (2011).

Schleich and Kästle (2002) noted a life span for the species of at least 19 years.

Population Status. - General surveys in many parts of the range of the species, including several sites in India (Moll 1984; Das 1986; Vyas and Patel 1990; Bhupathy and Vijayan 1991), and Bangladesh (Khan 1982) have revealed L. punctata as common and/or the most frequently observed of any turtle species, and Das (1991) reported that it may be the most common species in the Indian subregion. However, Verma and Sahi (1998) reported that this species is rare in Jammu and Kashmir State of India at the northern extreme of its range. No data are available to document historic changes in abundance.Aliterature compilation indicates that this species is recorded from at least 150 localities within India, and is common at 88 , uncommon at two, with status unknown at the remaining localities (Bhupathy, unpubl.data). Choudhury et al. (2000) considered the species common and stable in India. As approximately one third of the locality records are from protected areas, such as wildlife sanctuaries and national parks where hunting is prohibited, the population status of this species within India may be considered stable.

Threats to Survival. - Lissemys punctata and its eggs are rather heavily exploited for food and it is one of the most frequently observed species in markets (Whitaker 1997). Some 50-70 thousand are sold each year (early 1980s) in the Howrah Market near Kolkata (Das 1991; Whitaker 1997). Choudhury et al. (2000) noted that L. punctata was the most common Indian softshell in the meat trade, and that habitat loss was not a major concern. Saha (1986) noted that, in the Sunderbans of West Bengal, about 400 Hindu and Christian families were engaged in the profession of catching wildlife to be sold to local markets, with L. punctata the most commonly caught turtle. In 1995 in the south Indian city of Coimbatore, turtles weighing 2-4 kg were sold at Indian Rupees 100-150 (Gupta and Rathinasabapathy 1995). Turtles are caught by nets, hooks, or by hand, with burrowed turtles located by probing with an iron-tipped bamboo stick. Rashid and Swingland (1997) noted turtles were easily collected at night, when they approach the shore in response (and seeming attraction) to the search lights. Recognizing that the trade in this species, despite its wide occurrence, is technically illegal, Choudhury and Bhupathy (1993) reported that wildlife authorities had confiscated 4053 individuals in Kolkata in 1991, 2735 in 1992, and 1134 in the first three months of 1993. One kg of turtle meat in the Kolkata market was sold at Rs. 50 (ca. US\$ 1). Choudhury et al. (2000) noted that some illegal exports occur.

Currently, it seems that due to stringent action taken by forest department officials in West Bengal, the state where this species is exploited the most, the turtle trade has either been controlled or gone underground. Gupta (2002) reported that turtle trade originating from northeast Indian states have now been stopped because of the dwindling population of turtles, including L. punctata. However, sporadic reports on the illegal harvest of this species are available in recent years

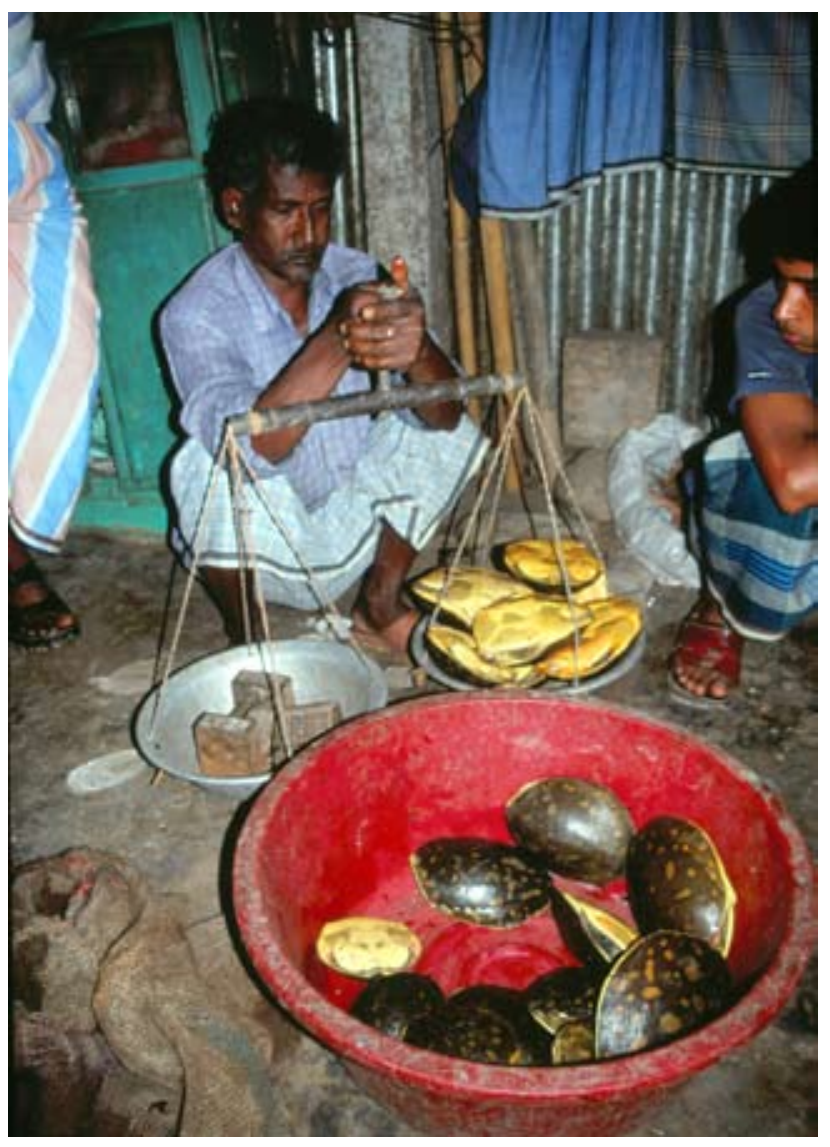

Figure 12. Lissemys punctata andersoni for sale in a market in Mongla, Bangladesh. Photo by Peter Praschag. 
from parts of India as well. For instance, the Uttar Pradesh State Police confiscated about 2000 L.punctata from Etawah (Gangetic plains) on 23 January 2010 (Rajeev Chauhan, pers. comm.). Krishankumar et al. (2009) reported $344 \mathrm{~L}$. punctata in a sample of 843 turtles collected in Punnamada village, Vembanad, Kerala, during 2007. Turtles were collected throughout the year for local consumption and the price ranged from Rs. 30-50 per turtle. Infrastructure development, especially roads and traffic, result in mortality of L. punctata; 10 of 34 reptiles killed in Etawah district of Uttar Pradesh were this species (Gopi Sundar 2004). Turtle trade is banned in Bangladesh, but many turtles are still sold in Hindu festivals. During the Kali Puja festival in November 2013 in Dhaka, an estimated 7000 L.p.andersoni were sold for almost US\$ 8/kg (Morshed, pers. comm.).

Shrestha (1996) reported that an extract from genital organs was prescribed to pregnant women in Nepal to make childbirth easier. Schleich and Kästle (2002) noted a large number of turtles are caught to supply dissection material to schools and universities.

Nath (1958) reported the prehistoric use of this species by the Indus Valley Civilization (Mohenjodaro and Harappa, India, 5000 YBP) and in Saranath (Uttar Pradesh, India, 2330 YBP) based on archeological excavations at these sites.

Live individuals are maintained for sundry ritualistic and religious reasons, and are often kept in wells and water tanks to consume aquatic organisms (Das 1991). Some turtles probably are sacrificed for the artifact trade (dried whole specimens, shells, masks). Rai in Schleich and Kästle (2002) noted that, in Nepal, pieces of the shell are kept in the house as a lucky charm, and also reported that powder made out of the shell are fed to cattle as medicine; in some cases even to humans (Choudhury and Bhupathy 1993). Mahawar and Jaroli (2008) reported that L. punctata is one of the over 100 animal taxa used in traditional medicine in different parts of India.

Despite their predominantly scavenging habits, these turtles are often believed to prey upon commercial fish species; thus, they are frequently killed by fishermen when caught on baited hooks. Predatory pressure on turtle populations in local ponds increases with prolonged drought conditions (Bhupathy and Vijayan 1989). Tikader and Sharma (1985) commented on overexploitation of adults and their eggs for food, habitat destruction and urbanization of nesting sites, and the construction of dams that hamper movements, and they regarded populations as reduced and the species as endangered.

Conservation Measures Taken. - Riexinger (1984) noted that L.p.punctata (=L.p.andersoni) as of 1976 was listed under the Endangered Species Act (U.S. Fish and Wildlife Service), but was delisted in 1984. The species was originally listed in CITES Appendix I, but was downlisted to Appendix II in 1994. CITES has no jurisdiction over the extensive domestic trade in this species. Occurrence in many Indian national parks and wildlife sanctuaries (e.g., Keoladeo National Park) and Nepalese (Chitwan and Bardia National Parks) sanctuaries seemingly provide some measure of protection. The species receives theoretical protection under the Indian Wildlife (Protection) Act, Schedule I [highest order of protection] of 1972 (Das 1991, 2001; Whitaker 1997), and the Bangladesh Wildlife Preservation (Amendment) Act (BWPA), Schedule II, of 2012. Rashid and Swingland (1997) and Rashid and Khan (2000) noted the species was included in BWPA Schedule I. Whitaker (1997) suggested downlisting the species in India to Schedule IV, since it is the most common and widely distributed turtle.

Conservation Measures Proposed. - As a result of its heavy utilization for both subsistence and commerce (Choudhury and Bhupathy 1993), Moll (1984) recommended continuous monitoring and listing of the species under Schedule IV of the Indian Wildlife Protection Act that provides for protective regulations by state authorities. Schleich and Kästle (2002) proposed the species as Vulnerable in Nepal. Rashid and Khan (2000) noted the species was proposed as Vulnerable in the IUCN-Bangladesh 1999 Red Data Book. Since the species seems to be abundant in most areas of suitable habitat within its range, especially in India, it is proposed that its global conservation status on the IUCN Red List be retained as Least Concern.

Education programs should be implemented to inform local populations and fishermen of the usefulness of these turtles in consuming carrion and their negligible effect as predators on active healthy fish (most fish-eating seems to involve dead or dying fish and carrion); although such observations need to be more thoroughly documented. Some conservation effort is required to restrict wholesale commercial exploitation, and especially the collecting of eggs and gravid females during the nesting season. As the species thrives in captivity, a captive breeding program for limited commercial exploitation might be feasible to relieve the stress on wild populations. Currently, several infrastructure development projects such as highway construction are being executed in India. It is suggested that appropriate plans should be made to avoid or reduce mortality of herpetofauna, including turtles (Gopi Sunder 2004; Bhupathy et al. 2011).

Captive Husbandry. - Lissemys punctata thrives in captivity; thus, the species is amenable to successful captive breeding programs. Artificial incubation of eggs and hatching has been accomplished at the Madras Crocodile Bank Trust (MCBT) (Vijaya 1982; Whitaker 1997), with the last author noting the feasibility of rearing turtles in village ponds because of their scavenging tendencies and subsistence on household garbage such as vegetable wastes. Vijaya in Whitaker (1997) noted the species required about two years of growth to reach the harvestable size of $400-500 \mathrm{~g}$. The 
MCBT is continuing its effort to study the breeding biology of this species in captivity. During the mid 1980s, as part of the Turtle Rehabilitation Project, eggs of Lissemys (and other softshell turtles) were maintained and hatched in artificial hatcheries in Uttar Pradesh, such as the Saranath Turtle Breeding Centre, Varanasi, and at a captive rearing center at Kukrail near Lucknow with ultimate release in the Ganges River. Lissemys punctata is one of the most common turtles found in Indian zoological gardens. Of the 140 Indian zoos, many of them possess this species. A questionnaire survey conducted by Choudhury and Bhupathy (1993) revealed that of the 36 zoos responding with information about having turtles, 23 kept L. punctata. In many zoos, this species is placed with other animals (as scavengers) to clean areas of food leftovers. Hossain et al. (2008) suggested possible commercial turtle farming in Bangladesh.

Current Research. - We are not aware of any notable studies in progress at present. It is hoped that the recently launched project, Conservation and Action Plan for FreshwaterTurtles and Tortoises of India by the Madras Crocodile Bank Trust will provide much needed ecological information on Indian chelonians, including L. punctata.

Acknowledgments. - This work was supported by the Bombay Natural History Society, Mumbai; Sálim Ali Centre for Ornithology and Natural History, Coimbatore and The University of Texas at El Paso. RGW is grateful to Arthur H. Harris, University of Texas at El Paso, for circumventing early technical problems associated with word processing and electronic transmittal of this manuscript.

\section{LITERATURE CITED}

Agarwal, A.K. 1987. Observations on the sexual dimorphism in Indian freshwater tortoise Lissemys punctata punctata. Geobios 14:277-280

AnNANDALE, N. 1912.The Indian mud-turtles(Trionychidae). Records of the Indian Museum 7(2)(16):151-180.

AufFenBERG, W. 1981. Behaviour of Lissemys punctata (Reptilia, Testudinata, Trionychidae) in a drying lake in Rajasthan, India. Journal of the Bombay Natural History Society 78:487-494.

BAUR, G. 1893. Notes on the classification and taxonomy of the Testudinata. Proceedings of the American Philosophical Society 31:210-225.

Bнupathy, S. 1989. Morphometry of the Indian flapshell turtle (Lissemys punctata andersoni). Journal of the Bombay Natural History Society 86:252.

BhupATHY, S. 1990. Observations on the food of the Ganges soft-shell turtle Trionyx gangeticus in Keoladeo National Park, Bharatpur. Journal of the Bombay Natural History Society 87:460-461.

Bhupathy,S. AND BuHLMAnN,K.A.2010.Le Trionyx à clapets de l'Inde Lissemys punctata (Bonnaterre, 1789): Indian Flapshell Turtle. Chéloniens 18:24-28.

Bhupathy,S. AND ViJaYAn, V.S. 1989.Predation on the Indian flap-shell turtle (Lissemys punctata) in Keoladeo National Park, Bharatpur, Rajasthan.In: Patel, B.H.(Ed.). The Behaviour. Bhavnagar: Sir P.P. Institute of Science, Proceedings National Symposium of Animal
Behaviour,pp. 27-33

Bhupathy, S. AND ViJayan, V.S. 1991. The freshwater turtle fauna of Eastern Rajasthan. Journal of the Bombay Natural History Society 88:118-122.

BhUPATHY, S. AND ViJaYAN, V.S. 1993. Aspects of the feeding ecology of Lissemys punctata (Reptilia: Trionychidae) in Keoladeo National Park, Bharatpur, India. Hamadryad 18:13-16.

Bhupathy, S. AND ViJayan, V.S. 1994. Aestivation of turtles in Keoladeo National Park, Bharatpur with special reference to Lissemys punctata (Reptilia: Trionychidae). Journal of the Bombay Natural History Society 91:398-402.

Bhupathy, S., SRinivas, G., Sathishkumar, N., Karthik, T., and Madivinan, A. 2011. Herpetofaunal mortality due to vehicular traffic in the Western Ghats, India: a case study. Herpetotropicos 5(2):119-126.

BickHAM, J.W., Bull, J.J., AND LegleR, J.M. 1983. Karotypes and evolutionary relationships of trionychoid turtles. Cytologia 48:177-183.

BONNATERRE,M.1789.Tableau encyclopédiqueet méthodique destrois règnes de la nature. Erpétologie. Paris: Hôtel de Thou, 70 pp.

Boulenger, G.A. 1889. Catalogue of the Chelonians, Rhyncocephalians, and Crocodiles in the British Museum (Natural History). London: Taylor and Francis, $311 \mathrm{pp}$.

Bour, R. 1989. Comments on the authorship of the name Testudo (currently Pelusios) subnigra (Reptilia, Testudines). Bulletin of Zoological Nomenclature 46:192.

Buhlmann, K.A., Akre, T.S.B., Iverson, J.B., Karapatakis, D., Mittermeier, R.A., Georges,A., Rhodin,A.G.J., van DiJK, P.P., AND GibBons, J.W. 2009. A global analysis of tortoise and freshwater turtle distributions with identification of priority conservation areas. Chelonian Conservation and Biology 8(2):116-149.

Choudhury, B.C. AND Bhupathy, S. 1993. Turtle trade in India: a study of tortoises and freshwater turtles. New Delhi: World Wildlife Fund-India (prepared by TRAFFIC-India).

Choudhury, B.C., Bhupathy, S., AND Hanfee, F. 2000. Status information on the tortoises and freshwater turtles of India. In: van Dijk, P.P., Stuart, B.L., and Rhodin, A.G.J. (Eds.). Asian Turtle Trade: Proceedings of a Workshop on Conservation and Trade of Freshwater Turtles and Tortoises in Asia. Chelonian Research Monographs 2:86-94.

Daniel, J.C. 1983. The Book of Indian Reptiles. Bombay: Bombay Natural History Society, $141 \mathrm{pp}$.

DAs, I. 1985. Indian Turtles. A Field Guide. Calcutta: World Wildlife Fund-India (Eastern Region), 119 pp.

DAS, I. 1986. A survey of the batagur turtle of the Sunderbans with notes on other reptiles. Hamadryad 11:3-8.

DAs, I. 1991. Colour Guide to the Turtles and Tortoises of the Indian Subcontinent. Portishead: R \& A Publishing Limited, 133 pp.

DAS, I. 1995. Turtles and Tortoises of India. Bombay, India: Oxford University Press, 179 pp.

DAS,I.2001. Die Schildkröten des Indischen Subkontinents. Frankfurt am Main: Edition Chimaira, 183 pp.

DAS,K.C.AND GuPTA,A. 2011. Site records of softshell turtles(Chelonia: Trionychidae)from Barak Valley,Assam, northeastern India.Journal of Threatened Taxa 3:1722-1726.

DudA,P.L.ANDGUPTA, V.K.1981.Courtshipandmating behaviourof the Indian softshell turtle, Lissemys punctata punctata. Proceedings of the Indian Academy of Sciences (Animal Science) 90:453-461.

DudA, P.L. AND GuPTA, V.K. 1982. Transabdominal migration of ova in some freshwater turtles. Proceedings of the Indian Academy of Sciences (Animal Science) 91(2):189-197.

DumérIL, A.M.C. AND Bibron, G. 1835. Erpétologie Générale ou Histoire Naturelle Compléte des Reptiles. Tome second. Librairie 
Encyclopédique de Roret, Paris, 680 pp.

EHRENFELD,J.G.ANDEHRENFELD,D.W.1973.Externally secreting glands of freshwater and sea turtles. Copeia 1973:305-314.

FRAZIER, J.G. AND DAS, I. 1994. Some notable records of Testudines from the Indian and Burmese subregions. Hamadryad 19:47-66.

George, M.J. 1986. Cannibalistic behaviour of freshwater turtles in Keoladeo National Park, Bharatpur, Rajasthan. Journal of the Bombay Natural History Society 83:670-671.

GOPISUNDAR K.S.2004.Mortality of herpetofauna,birds and mammals due to vehiculartrafficinEtawahdistrict,UttarPradesh,India.Journal of the Bombay Natural History Society 101(3):392-398.

GraY, J.E. 1831. Synopsis Reptilium; or Short Descriptions of the Species of Reptiles. Part I. Cataphracta. Tortoises, Crocodiles, and Enaliosaurians. London: Truettel, Wurtz and Company, 85 pp.

GRAMENTZ,D.2011.Lissemys punctata- the Indian Flap-shelled Turtle. Frankfurt am Main: Edition Chimaira, 280 pp.

GuPTA,A. 2002. Beleaguered chelonians of northeast India. Turtle and Tortoise Newsletter 6:16-17.

GUPTA,B.K. ANDRATHINASABAPATHY,B.1995. Freshwaterturtles: Illegal trade in Coimbatore, South India. Cobra 22:20-21.

Hossain, M.L. AND SARKAR, M.S.U. 1999. Albino spotted flap-shell turtle (Lissemys punctata) in Bangladesh. Tiger paper 26:14.

Hossain, M.L., SARKer, S.U., AND SARKer, N. J. 2008. Ecology of spotted flapshell turtle, Lissemys punctata (Lacepède, 1788) in Bangladesh. Ecoprint 15:59-67.

Hutchison, V.H., Vinegar, A., AND Kosh, R.J. 1966. Critical thermal maxima in turtles. Herpetologica 22:32-41.

ICZN [International Commission of Zoological Nomenclature]. 1987. Opinion 1463 [Case 1985]. De Lacépède, 1788-1789, Histoire Naturelle des Serpens and latereditions: rejected as a non-binominal work. Bulletin of Zoological Nomenclature 44:265-267.

iCZN [International Commission of Zoological Nomenclature]. 2005. Opinion 2104 (Case 3226). Lacepède, B.G.É. de la V., 1788. Histoire Naturelle des Quadrupèdes Ovipares: rejected as a nonbinomial work. Bulletin of Zoological Nomenclature 62:55.

IVERSON,J.B. 1992.ARevised Checklist with Distribution Maps of the Turtles of the World. Richmond, IN: Privately printed, $363 \mathrm{pp}$.

JoyCE, W.G. AND Lyson, T.R. 2010. A neglected lineage of North American turtles fills a major gap in the fossil record.Palaeontology 53(2):241-248.

KHAN,M.A.R.1982.Chelonians of Bangladesh and their conservation. Journal of the Bombay Natural History Society 79:110-116.

Khan, M.S. 2006. Amphibians and Reptiles of Pakistan. Malabar: Krieger Publishing Company, 311 pp.

Krishnakumar, K., Raghavan, R., and Pereira, B. 2009. Protected on papers, hunted in wetlands: exploitation and trade of freshwater turtles (Melanochelys trijuga coronata and Lissemys punctata punctata) in Punnamada, Kerala, India. Tropical Conservation Science 2(3):363-373.

LaCÉPÈDE, B.G.E. DE. 1788. Histoire Naturelle des Quadrupèdes Ovipares et des Serpens. Tome Premier, Ed. 26 cm. Paris: Hôtel de Thou, $651 \mathrm{pp}$.

MAHAWAR, M.M. AND JAROLI, D.P. 2008. Traditional zootherapeutic studies in India: a review. Journal of Ethnobiology and Ethnomedicine 4:17, doi:10.1186/1746-4269-4-17.

MERTENS, R. AND WeRmuth, H. 1955. Die rezenten schildkröten, krokodile und brückenechsen. Zoologische Jahrbücher (Systematik) 83:323-440.

Minton S.A., JR. 1966. A contribution to the herpetology of west Pakistan. Bulletin of the American Museum of Natural History 134:27-184.

MisHRA,S.B.1986.Observations on the nesting of two soft-shell turtles, Chambal River, Uttar Pradesh. Hamadryad 11(1-2):15-16.
MisHRA, S.B. 1987. Observations on freshwater turtle egg predation. Hamadryad 12(1):12.

Mitchell, J.C. AND RHODIN, A.G.J. 1996. Observations on the natural history and exploitation of the turtles of Nepal, with life history notes on Melanochelys trijuga. Chelonian Conservation and Biology 2(1):66-72.

MoLL,E.O. 1984.Freshwater turtles in India: their status, conservation and managment. Hamadryad 9(3):9-17.

Moll, D. And Moll, E.O. 2004. The Ecology, Exploitation, and Conservation of River Turtles. New York: Oxford University Press, 393 pp.

NATH, B. 1958. Animal remains from Sarnath, U.P. Journal of the Zoological Society of India 10:168.

Praschag, P., S., Stuckas, H., PÄckert, M., Maran, J. and Fritz, U. 2011. Mitochondrial DNA sequences suggest a revised taxonomy of Asian flapshell turtles (Lissemys SMITH, 1931) and the validity of previously unrecognized taxa (Testudines: Trionychidae). Vertebrate Zoology 61:147-160.

RASHID, S.M.A. AND KHAN, S.M.M.H. 2000. Trade and conservation status of freshwater turtles and tortoises in Bangladesh. In: van Dijk, P.P., Stuart, B.L., and Rhodin, A.G.J. (Eds.). Asian Turtle Trade: Proceedings of a Workshop on Conservation and Trade of Freshwater Turtles and Tortoises in Asia. Chelonian Research Monographs 2:77-85.

RASHID, S.M.A. AND SwINGLAND, I.R. 1997. On the ecology of some freshwaterturtles in Bangladesh.In: Van Abbema,J.(Ed.),Proceedings: Conservation, Restoration, and Management of Tortoises and Turtles-AnInternationalConference. New YorkTurtle and Tortoise Society, pp. 225-242.

RIEXINGER, P. 1984. Legislative alert. Federal register notices. Herpetological Review 15:63-64.

RoHILla, M.S., RaO, R.J. and TiWari, P.K. 2009. Enzyme polymorphism in Indian freshwater soft shell turtle Lissemys punctata. Acta Herpetologica 4(1):15-28.

SAHA, B.K. 1986. Exploitation of reptiles and amphibians in the Sunderbans, West Bengal. Hamadryad 11(1-2):36.

SARKAR, S., SARKAR, N.K., AND MaITI, B.R. 1995. Histological and functional changes of oviductal endometrium during seasonal reproductive cycle of the soft-shelled turtle, Lissemys punctata punctata. Journal of Morphology 224:1-14.

SARKAR,S.,SARKAR,N.K.,DAS,P.ANDMAITI,B.R.1996a.Photothermal effects on ovarian growth and function in the soft-shelled turtles Lissemys punctata punctata. Journal of Experimental Zoology 274:41-55.

SARKAR, S., SARKAR, N.K. AND MAITI, B.R. 1996b. Seasonal pattern of ovarian growth and interrelated changes in plasma steroid levels, vitellogenesis, and oviductal function in the adult female soft-shelled turtle Lissemys punctata punctata. Canadian Journal of Zoology 74:303-311.

SARKar, S., SARKar, N.K. AND MaITI, B.R. 2003. Oviductal sperm storage structure and their changes during the seasonal (dissociated) reproductive cycle in the soft-shelled turtle Lissemys punctata punctata. Journal of Experimental Zoology 295A:83-91.

SAVAGE,J.M.2003.Lacepède,B.G.É.de laV., 1788, Histoire Naturelle Des Quadrupèdes Ovipares: proposed rejection as a non-binominal work. Bulletin of Zoological Nomenclature 60:138-140.

SCHLEICH,H.H. ANDKäSTLE,W.(Eds.). 2002.Amphibians and Reptiles of Nepal. Ruggell: A.R.G. Ganter Verlag K.G., 1201 pp.

SchOEPFF, J.D. 1792-1801. Historia Testudinum Iconibus Illustrata (Latin ed.); Naturgeschichte der Schildkröten mit Abbildungen erläutert (German Ed.). Erlangen, 136 (Latin Ed.), 160 pp.

Sharma, R.C. And VaZIRANI, T.G. 1977. Food and feeding habits of some reptiles of Rajasthan. Records of the Zoological Survey of 
India 73:77-93.

SHRESTHA, T.K. 1996. Country Report for Nepal. In: Abstracts: International Conference on the Biology and Conservation of the South Asian Amphibians and Reptiles, 1-5, Sri Lanka, August, 1996.

SHRESTHA, T.K. 1997. Status, biology, conservation, and management of tortoises and turtles in the Himalayan foothills of Nepal. In: Van Abbema, J. (Ed.), Proceedings: Conservation, Restoration, and Management of Tortoises and Turtles--An International Conference. New York Turtle and Tortoise Society, pp. 278-286.

SiEBENROCK, F. 1902. Zur systematik der schildkrötenfamilie Trionychidae Bell, nebst der beschreibung einer neuen Cyclanorbis-art. Sitzungsberichten der Kaiserlichen Akademie der Wissenschaften in Wien. Mathem.-naturw. Classe 91:807-846.

SIEBENROCK, F. 1909. Synopsis der rezenten schildkröten, mit berücksichtigung derin historischerzeit ausgestorbenen arten.Zoologische Jahrbücher, Supplement 10, 3:427-618.

SiNGH, D.P. 1977. Annual sexual rhythm in relation to environmental factors in a tropical pond turtle, Lissemys punctata granosa. Herpetologica 33:190-194.

Sivasubramanian, C. AND Bhupathy, S. 1990. Indian flapshell turtle Lissemyspunctata in the food of the adjutant stork Leptoptilosdubius. Journal of the Bombay Natural History Society 87:460.

SмIтн, M.A. 1931. The Fauna of British India, including Ceylon and Burma. Reptilia and Amphibia. Vol. I. Testudines. London: Taylor and Francis, 185 pp.

TALUKDAR, S.K. 1979. Lissemys punctata punctata (Bonnaterre) [Testudines: Trionychidae]: an addition to the chelonian fauna of the Brahmaputra drainage, Assam. The Indian Journal of Zootomy 20(3): 181

TIKADER, B.K. AND Sharma, R.C. 1985. Handbook Indian Testudines. Calcutta: Zoological Survey of India, 156 pp.

VARGHESE, G. AND TONAPI, G.T. 1986. Observations on the identity of some Indian freshwater turtles and their feeding habits. Biological Conservation 37:87-92.

Verma, A.K. AND SAHI, D.N. 1998. Status, range extension and ecological notes on Indo-Gangetic flapshell turtle, Lissemys punctata andersoni (Testudines: Trionychidae) in Jammu Shiwaliks, J \& K state. Cobra 34:6-9.

VIJAYA, J. 1982. Successful artificial breeding of Lissemys punctata granosa. Journal of the Bombay Natural History Society 79:210 211

VYAS, R. 1996. Breeding data on Lissemys punctata from western
India. Hamadryad 21:45-47.

VYAS, R. 1997. An albino form of the Indian flapshell turtle (Lissemys punctata). Hamadryad 22:62-63.

VYAS,R. ANDPATEL,B.H.1990.Asurvey of freshwaterturtles of Gujarat. Journal of the Bombay Natural History Society 87:152-155.

WEBB, R.G. 1980. The identity of Testudo punctata Lacepède, 1788 (Testudines, Trionychidae). Bulletin de Muséum National Histoire Naturelle, Paris, Series 4, 2(sec. A, no.2):547-557.

WeBb, R.G. 1982. Taxonomic notes concerning the trionychid turtle Lissemys punctata (Lacepède). Amphibia-Reptilia 3:179-184.

WHITAKER, R. 1997. Turtle rearing in village ponds. In: Van Abbema, J.(Ed.). Proceedings: Conservation, Restoration, and Management of Tortoises and Turtles--An International Conference. New York Turtle and Tortoise Society, pp. 106-108.

WhitAKER, R. AND ANDREWs, H.V. 1997. Captive breeding on Indian turtles and tortoises at the Centre for Herpetology/Madras Crocodile Bank. In: Van Abbema, J.(Ed.), Proceedings: Conservation, Restoration, and Management of Tortoises and Turtles--An International Conference. New York Turtle and Tortoise Society, pp. 166-170.

YADAV, M.R. 1989. Reproductive potential of Indian tropical pond turtle Lissemys punctata granosa (Schoepff). Indian Journal of Forestry 12(4):276-279.

YADAVA, M. R. AND B. PRASAD. 1982. Observations on the breeding biology of Indian tropical pond turtle, Lissemys punctata granosa (Schoepf), Uttar Pradesh. The Indian Journal of Zootomy 23:51-56.

YoNG, K. 1990. On two species of softshell turtles native to Singapore, including a note on Lissemys punctata (Lacepede, 1788) (Reptilia: Testudines: Trionychidae). Raffles Bulletin of Zoology 38(1):27-30.

\section{Citation Format for this Account:}

Bhupathy, S., WebB, R.G, and Praschag,P. 2014. Lissemys punctata (Bonnaterre 1789) - Indian Flapshell Turtle. In: Rhodin, A.G.J., Pritchard,P.C.H., van Dijk, P.P., Saumure, R.A., Buhlmann, K.A., Iverson,J.B., and Mittermeier, R.A.(Eds.). Conservation Biology of Freshwater Turtles and Tortoises: A Compilation Project of the IUCN/SSC Tortoise and Freshwater Turtle Specialist Group. Chelonian Research Monographs No.5,pp.076.1-12, doi:10.3854/ crm.5.076.punctata.v1.2014, http://www.iucn-tftsg.org/cbftt/. 